\title{
EXPLORING THE FACTORS THAT HAVE IMPACT ON CONSUMERS' TRUST IN MOBILE PAYMENT SYSTEMS IN AUSTRALIA
}

Domingos Yamaguti Mondego https://orcid.org/0000-0001-6777-3639

Ergun Gide https://orcid.org/0000-0003-2258-1910

Central Queensland University, Queensland, Australia

\begin{abstract}
Trust plays a vital role in the adoption of a new payment system in so far as people need to trust that the prevailing currency, or in other words, money, is recognised by all stakeholders. With the evolution of the payment methods, shifting from paper-based to electronic-based, building consumer trust has become a vital element for the success of businesses involved in the mobile payment systems sector. In this context, the aim of this study was to delve deeper into the factors that have impact on consumers trust in mobile payment systems (MPS) in Australia. A quantitative approach through a questionnaire survey was conducted to measure the data collected. The data of 200 participants were gathered using SurveyMonkey and the Excel spreadsheets was imported into SPSS (Statistical Package for the Social Sciences) system, where the data were organised. Besides, this study adopted the Partial Least Square Structural Equation Modeling (PLS-SEM), where the data analysis took place. The findings of PLSSEM analysis pointed out that behavioural factors and organisational factors have significant impact on consumers' trust, and this, as a consequence, have influence on MPS adoption. On the other hand, this research found that the technological factors, governmental factors and personal factors have no significant impact on Australian consumers' trust and this, as a result, has no influence on MPS adoption.
\end{abstract}

Keywords: Mobile payment systems, MPS, trust, consumers, influencing factors, Australia

Manuscript first received: 2019-05-09. Manuscript accepted: 2020-10-11

Address for correspondence:

Domingos Yamaguti Mondego. Central Queensland University, Queensland, Australia. Email: dmym@hotmail.com

Ergun Gide. Central Queensland University, Queensland, Australia. Email: e.gide1@cqu.edu.au 


\section{INTRODUCTION}

The traditional payment systems have been affected by the emergence of electronic commerce, or e-commerce, and this has changed the way people pay their bills. The arrival of e-commerce has been facilitating economic transactions between businesses and consumers and transforming the way people buy and pay for goods and services received. As a result, online banking transactions have emerged as an evolutionary path to the payment process to respond to the dramatic increase in electronic transactions.

A study conducted by the Australian Payment Clearing Association (APCA 2016, p.8) pointed out that 'online banking is the most popular web activity for the $86 \%$ of households with internet access in Australia'. It is consistent with a previous study conducted by the Australia Bureau of Statistics (ABS, 2016a), which also highlighted that currently 'of the 7.7 million households with internet access, 94\% connected via laptops or desktop computers, $86 \%$ via mobiles or smartphones, and 62\% via tablets' (Australian Payment Clearing Association, 2016, p.8).

Over the past years, the number of Australians who access the internet from a wide range of devices, especially mobile devices, has been increasing, reaching $84 \%$ in 2016 , up from $76 \%$ in 2014 (APN 2017, p.7). The ubiquity of mobile devices has changed the way consumers shop across Australia in so far as they can use their mobile devices to buy goods and services, as well as to make payments online and at point-of-sale (POS). Furthermore, the mobile payment systems (MPS) allows users to purchase, transfer money, and pay bills by accessing banking accounts from their smartphones or mobile devices. Moreover, Australians can 'access online banking and payment apps [applications] through their smartphones, [which enables] the phone to replace the physical card or to provide an alternate means of making or accepting a payment' (Australian Payments Council 2015, p.9).

In this sense, the increasing acceptance of the electronic payment systems by users can be associated with the evolution of mobile technology. However, researchers have pointed out that there are several factors, besides the evolution of the mobile devices, that can have a positive or a negative effect on trust in mobile payment systems. Cao, Dang and Nguyen (2016, p.117), for instance, stated that 'perceived trust is the strongest predictor of intention to use mobile payment services'. Kristensen (2016, p.62), 'revealed Danish consumers' intention to use mobile payment at point-ofsale is influenced by perceived usefulness, compatibility, social influence and perceived trust'. Xin (2013, p.vi) hold the view that 'a high degree of uncertainty avoidance negatively affects trust in mobile payment [and] a high level of trust disposition positively relates to trust in mobile payment'. Köster, Matt and Hess (2016, p.33) indicated that 'they can improve consumers' transaction intention relatively inexpensively by embedding a trustworthy mobile payment provider'. In contrast to the business view and trust factors, Liébana-Cabanillas, Sánchez-Fernández and Muñoz-Leiva (2014a, 2014b) have studied the personal factors of the users such as age and gender that have impact on mobile payments adoption.

Thus, there is a growing interest from the academic community in investigating what factors might have impact on consumers' trust and its influence on the MPS adoption. These enquiries lead to the following sections. 


\section{LITERATURE REVIEW}

\section{Trust}

Trust has been the focus of several studies over the past years. Many researchers have been studying the effects of trust in users' intention to adopt the mobile payment systems (MPS). A study conducted by Duane, O'Reilly and Andreev (2014, p.318), affirmed that the strongest element that affects the intent of people to utilise their smartphones to make payments is trust. This is consistent with previous research conducted by Xin, Techatassanasoontorn and Tan (2013, p.1), which highlighted that trust is a fundamental element that has impact on consumers' intention to use the MPS. In addition, Dastan and Gürler (2016, p.21) pointed out that perceived trust have a positive impact on the adoption of MPS, which was also endorsed by Mahad, Mohtar and Othman (2015, p.6) who emphasized the positive effects of perceived trust on consumers' intention to adopt the mobile banking. Finally, Gong et al. (2016, p.1) found out that emotional trust strongly affects the willingness of consumers to use the MP, whilst cognitive trust impacts directly and indirectly on users' intention.

Thus, as it can be seen clearly, trust plays an essential role on mobile payments adoption. In addition, it is noteworthy to mention that various authors have been focusing their studies on different aspects of the users, merchants, banks and providers in order to comprehend what might be the factors that have driven or inhibited users from adopting the MPS. Furthermore, it is worth mentioning that this study took into account only studies where trust was part of the research model tested by academics.

In this context, as preliminary stage of this study, 76 recent studies, conducted from 2013 to 2017, were separated in order to point out and shed some light on the factors that have impact on mobile payments adoption. It is also important to mention that the preliminary stage of this study pointed out that 59 surveys, 9 interviews and 8 literature reviews were conducted by the authors. Besides, Table 1 summarises the influencing factors that have impact on MPS adoption, according to the studies conducted during the period analysed (2013 - 2017).

Thus, as it can be seen, the reasons that lead people to adopt the mobile payment systems present a wide range of combinations and results, in so far as the approach of the authors focus on determined aspects of the users, merchants, banks and providers.

Based on these previous studies, which tested trust as one of the constructs, this research continues to examine the influencing factors that have impact on consumers' trust.

\section{Factors that have influence on trust}

In the previous section, the factors that have impact on consumers' intention to adopt the MPS were highlighted according to various authors' studies. In addition, it is worth mentioning that this study took into account only research models or studies in which trust was tested as one of the constructs. In this context, as various studies pointed out different results in relation to the impact of those factors on MPS adoption, as well as it was not clear the influence of trust on consumers' intention to adopt the MPS, this study has divided those factors into 5 distinct categories: organisational factors, technological factors, behavioural factors, personal factors and governmental factors. 
Table 1. Factors that have influence on the intention to adopt the MPS according to studies conducted from 2013 to 2017

\begin{tabular}{|c|c|c|c|}
\hline \multicolumn{4}{|c|}{ Influencing factors } \\
\hline Trust & Perceived Usefulness & Perceived ease of use & Perceived risk \\
\hline Performance expectancy & Social influence & Compatibility & Perceive security levels \\
\hline Attitudes & Effort expectancy & Perceived cost & Subjective norms \\
\hline Innovativeness & Behavioural intention & Age & Facilitating conditions \\
\hline $\begin{array}{l}\text { Mobile Payment Experience / MP } \\
\text { knowledge }\end{array}$ & Providers' trustworthiness & Gender & Perceived mobility \\
\hline Perceived reputation & User satisfaction & Structural assurance & Hedonic motivation \\
\hline Privacy risk & Perceived convenience & Price value & $\begin{array}{l}\text { Perceived benefit / relative } \\
\text { advantage }\end{array}$ \\
\hline Self-efficacy & Perceived enjoyment & Perceived system quality & Perceived service quality \\
\hline Perceived uncertainty & Habit & Perceived safety & Perceived behavioural control \\
\hline Technology factors & Network externalities/ effects & Perceived financial resources & Perceived Information quality \\
\hline Environmental risk & $\begin{array}{l}\text { Users' awareness / informal } \\
\text { learning }\end{array}$ & Involvement & Ubiquity \\
\hline Flow & Income & Demand factors & Dependencies \\
\hline Perceived value & Openness to third parties & Perceived asset & Enticing promises \\
\hline Impulsiveness & Fingerprint recognition technology & Consumers' lifestyle & Switching costs \\
\hline Governance issues & Use of PIN & Device-design suitability & Familiarity \\
\hline Transparency & Consumers' willingness & Situational factors & Organisational factors \\
\hline Conflicts & Strategic objectives and interests & Pre-purchase anxiety & Development of new products \\
\hline service availability & Perceived entitativity & Perceived expressiveness & $\begin{array}{l}\text { Maintaining a relationship with } \\
\text { customers }\end{array}$ \\
\hline Ethnicity & Inter-organisational factors & Find policies & Environmental factors \\
\hline Attractiveness & Trusted Service Manager (TSM) & Scale & Word of mouth \\
\hline Ability & Reference groups & Marital status & Benevolence \\
\hline Integrity & Occupation & Location & Trialability \\
\hline Exposure & Social image & Users' characteristics & Information searching \\
\hline $\begin{array}{l}\text { Assessment of the functional } \\
\text { reliability of MPS }\end{array}$ & $\begin{array}{l}\text { Additional values of NFC mobile } \\
\text { payment }\end{array}$ & Absorptive capacity & Mobile advertisement effect \\
\hline $\begin{array}{l}\text { Ease of issuing and distributing } \\
\text { solutions }\end{array}$ & Socio-economic sector & Utility & Fast transactions \\
\hline Company's number of workers & Company's income & Sales channels & Role in the company \\
\hline $\begin{array}{l}\text { Experience with traditional } \\
\text { payment systems }\end{array}$ & $\begin{array}{l}\text { Typology of payment systems } \\
\text { approached }\end{array}$ & Payment system's providers & Digital lifestyle \\
\hline Interaction & Electronic readiness & Complexity & \\
\hline
\end{tabular}

\section{Organisational factors}

Organisational factors refer to all service providers, financial institutions and vendors across the country that have been investing and providing an electronic payment ecosystem to their customers and, hence, replacing the need of cash or face-to-face business negotiations. This includes organisations involved in the mobile payment sector that need to take the necessary measures to protect 
customers' information and prove that their systems are fully functional. Xin (2013, p.vi) suggested that perceived environmental risk, structural assurance, as well as the reputation of both vendors and the service providers have influence on consumers' trust. It was also affirmed by Zhou (2013, p.1085) who indicated that trust is strongly affected by service quality. In addition, Shaw (2014) highlighted the concerns about security and privacy, which have a significant influence on trust. However, this view was contested by Teoh et al. (2013) who revealed that trust and security have insignificant results on consumers' perception towards e-payment. Table 2 summarizes the organisational factors that affect trust based on the studies conducted from 2013 to 2017.

Table 2. Organisational factors that affect trust

\begin{tabular}{|c|c|c|c|c|c|}
\hline \multicolumn{6}{|c|}{ Organisational factors } \\
\hline Transparency & $\begin{array}{l}\text { Providers' } \\
\text { trustworthiness }\end{array}$ & Conflicts & Environmental risk & Scale & Switching costs \\
\hline Environmental factors & $\begin{array}{l}\text { Development of new } \\
\text { products }\end{array}$ & $\begin{array}{l}\text { Trusted Service } \\
\text { Manager (TSM) }\end{array}$ & Network externalities & Innovativeness & $\begin{array}{l}\text { Inter-organisational } \\
\text { factors }\end{array}$ \\
\hline Situational factors & $\begin{array}{l}\text { M Openness to third } \\
\text { parties }\end{array}$ & Service availability & Involvement & Facilitating conditions & Structural assurance \\
\hline $\begin{array}{l}\text { Assessment of the } \\
\text { functional reliability } \\
\text { of MPS }\end{array}$ & Demand factors & $\begin{array}{l}\text { Strategic objectives } \\
\text { and interests }\end{array}$ & $\begin{array}{l}\text { Maintaining a } \\
\text { relationship with } \\
\text { customers }\end{array}$ & Enticing promises & $\begin{array}{l}\text { Easy of Issuing and } \\
\text { distributing solutions }\end{array}$ \\
\hline Socio-economic sector & $\begin{array}{l}\text { Company's number of } \\
\text { workers }\end{array}$ & Company's income & Sales channels & $\begin{array}{l}\text { Payment system's } \\
\text { provider }\end{array}$ & $\begin{array}{l}\text { Typology of payment } \\
\text { systems approached }\end{array}$ \\
\hline Fast transactions & Electronic readiness & $\begin{array}{l}\text { Additional values of } \\
\text { NFC mobile payment }\end{array}$ & Absorptive capacity & $\begin{array}{l}\text { Mobile advertisement } \\
\text { effect }\end{array}$ & Role in the company \\
\hline
\end{tabular}

\section{Technological factors}

Technological factors are represented by the advances in mobile devices technology, for instance, 3G, 4G, the new generation of smartphones, mobile point-of-sale (MPOS) and so forth. They have impact on people's decision to adopt or not a different payment system in so far users need to have experience or at least understand how the mobile payment systems work. In addition, by comprehending how MP works, users could act differently. This was confirmed by Slade et al. (2015, p.860) who affirmed that MP knowledge, as a moderator factor, affects users' trust and this, as a result, produces a relevant effect on behavioural intention of the users to adopt the remote mobile payments (RMPs).

Hillman et al. (2014, p.253) highlighted that an improved design could bring a superior mobile payment experience to the users, as well as the development of trust mechanisms, the inclusion of user's behaviours, routines and gamification could resolve the users experience challenges. Table 3 summarises the technological factors that affect trust, according to the literature review.

Table 3. Technological factors that affect trust

\begin{tabular}{ccccc}
\hline & \multicolumn{3}{c}{ Technological factors } \\
\hline Device-design suitability & Ubiquity & Fingerprint recognition technology & Use of PIN \\
\hline
\end{tabular}




\section{Behavioural factors}

Behavioural factors are represented by the users' perception of the benefits and risks of using a new gadget or service (e.g. perceived risk, perceived benefit, perceived security, perceived uncertainty, and so on). In their studies about the intention to use the MPS, Chen and Li (2016, p.1), for instance, indicated that while post-adoption perceived risk was negatively affected by institutional-based trust, post-adoption perceived usefulness was positively influenced by it. Gao and Waechter $(2015$, p.1) highlighted the positive impact that trust has on perceived convenience and perceived benefit, and how the intention of use of the mobile payment services can be predicted by these three influencing factors. Zhou (2015, p.56) has shown that trust, satisfaction and flow, as an enablers, have influence on the intention to switch services. Wang, Fan and Zhang $(2015$, p. 198) found out that the adoption by users of e-payment tools are strongly determined by perceived benefit and trust, and less by perceived risk. In addition, Yan and Pan (2015, p.136) indicated that whilst MP trust is directly impacted by trust in online payment, perceived usefulness, structural assurance and perceived ease of use are indirectly influenced by it.

On the other hand, various authors emphasised that several factors have impact on trust. Yan and Yang (2015, p.117) confirmed in their studies that user's trust is significantly affected by perceived ease of use, ubiquity, structure assurance and perceived usefulness and this, consequently, has a relevant effect on user's willingness to use the MPS. Additionally, Shuhaiber (2016, p.II) suggested that trust is strongly influenced by customers' uncertainty avoidance, which is considered the most negative factor that has influence on mobile payment adoption, followed by perceived privacy risks. Finally, Yang et al. (2015, p.9) have shown that 'in the current stage of China's online payment, consumers have built up trust first as an antecedent of their perceived risks'. In this context, Table 4 highlights the behavioural factors that have impact on trust, according to previous studies conducted between 2013 and 2017 .

Table 4: Behavioural factors that affect trust

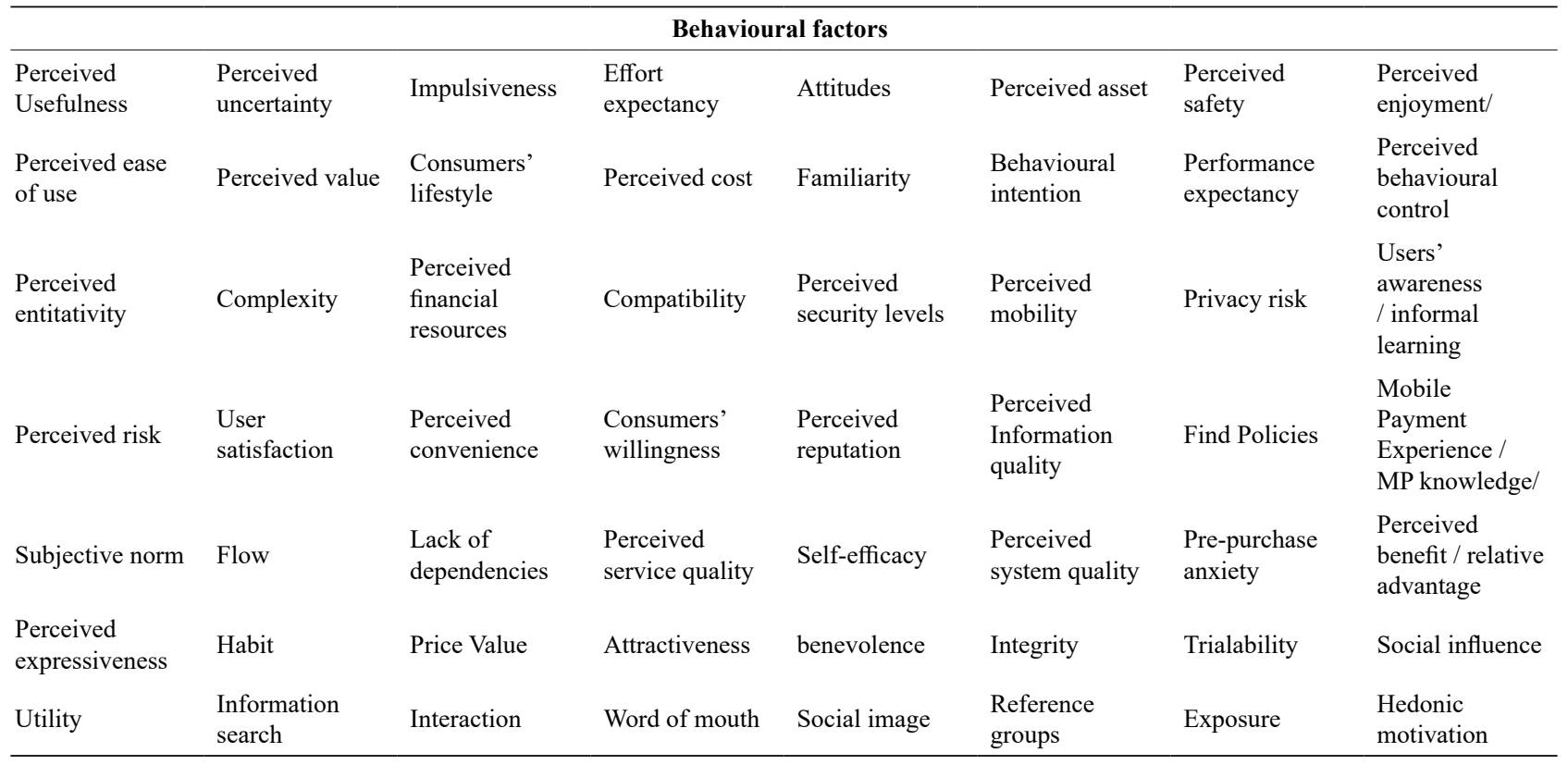




\section{Personal factors}

Personal factors are related to the diversity of the users such as age, gender, income and so forth. Several researchers have been investigating the personal aspects of consumers that have influence on trust and how it has impact on MPS adoption. Xin, Techatassanasoontorn and Tan (2013, p.11), for instance, analysed the influence of ethnicity as a cultural factor in the mobile technology adoption in New Zealand and suggested that the cultural background of individuals affects their trusting behaviour, and it in turn, has impact on mobile payment adoption. Additionally, Yoon and Occeña (2015, p.359), highlighted in their studies that in the C2C e-commerce market, trust is affected by the users' age, however, they did not observe any significant influence of gender. In contrast, LiébanaCabanillas, Sánchez-Fernández and Muñoz-Leiva (2014b, p.220) stated that:

The gender of the user introduces significant differences in the proposed relationships between ease of use and usefulness of the new system, between usefulness, attitude and intention to use, as well as between users' trust and a favourable attitude towards its use.

Finally, Chong (2013,p.528) examined through the neural network model, the various predictors, including the 'demographic profiles (e.g. age, gender and educational level) that have influence on mobile commerce adoption. Chong concluded that the gender of users has an insignificant impact on predicting the adoption of $\mathrm{m}$-commerce, however younger and higher educated people are more prone to adopt it. In this sense, Table 5 outlines the personal factors that have influence on trust.

Table 5. Personal factors that affect trust

\begin{tabular}{ccccc}
\hline \multicolumn{4}{c}{ Personal factors } \\
\hline Age & Gender & Income & Ethnicity & Education \\
Marital status & Users' characteristics & Occupation & Location & Digital lifestyle \\
\hline
\end{tabular}

\section{Governmental factors}

Governmental factors could be described as the impact of government policies on people's intention to use any sort of electronic payment. A study conducted by de Reuver et al. $(2015$, p.342) pointed out that in nations where decision-making is more centralised, governments are responsible for implementing the innovations of mobile payments projects, and this consequently can reduce trust between stakeholders (government, banks and telecoms) and lead to governance issues.

Another point that can illustrate the impact of government policies took place in India in 2016, where the effects of removing banknotes from circulation had an immediate effect on peoples' lives in so far as they needed to switch from a paper-based payment to alternative means of payments such as credit and debit cards, pre-paid cards, Internet and mobile banking. In the aftermath of the demonetization plan in India, digital payments were rapidly adopted by a great part of the population (Pachare 2016, p.180). Table 6 points out the governmental factors that have influence on trust, according to the literature.

Table 6. Governmental factors that affect trust 


\section{Proposed research framework to build trust in MPS for Australian consumers}

In the previous section, the factors that have influence on trust were divided into 5 different groups in order to simplify the recent studies. In addition, it is noteworthy to mention that these factors are not isolated events, but the combination among them, as the studies highlighted, has impact on consumers' trust and their intention to adopt the MPS.

Therefore, building trust has become a critical factor for organisations to succeed. It has a direct influence on MPS adoption in so far as it has become more difficult to keep a relationship with customers, especially when the contacts in person have sharply decreased (Bourreau and Valetti 2015, p.31). Moreover, as it has become more complicated to keep a relationship with all parts involved, there is a need for service providers to focus on building initial trust in users in so far as it could facilitate their MPS usage (Zhou 2014b, p.1519).

Besides, despite these studies highlighted the factors that affect trust, none of them have provided a framework of how to build consumers' trust in MPS within Australian context. Also, none of these studies have indicated to which extent trust can affect consumers' behaviour in Australia. Thus, it becomes essential to understand whether this relationship could have impact on the adoption of MPS, because it clearly shows that there is a knowledge gap in the subject-matter.

Thus, in order to understand the influencing factors that affect consumers' trust, and in turn, the MPS adoption, this study will investigate the proposed conceptual research framework, which represents the 5 distinct groups analysed above, in order to develop a framework of trust in MPS for Australian consumers (Figure 1).

\section{RESEARCH METHODOLOGY}

This study conducted a quantitative approach through a questionnaire survey in order to measure the data collected. The online questionnaire survey was set and conducted through the SurveyMonkey website. The target population was Australian consumers 18 and over with different socio-demographic characteristics (age, gender, income, educational levels and ethnicity). Respondents were encouraged to identifying themselves in different groups in order to eliminate bias in relation to group identification and facilitate the data analysis.

The data of 200 participants were gathered in Excel spreadsheets and after it was imported into SPSS (Statistical Package for the Social Sciences) system, where the data were organised. Besides, this study adopted the Partial Least Square Structural Equation Modeling (PLS-SEM), where the data analysis took place.

\section{DATA ANALYSIS}

\section{PLS-SEM analyses}

Partial least squares structural equation modeling (PLS-SEM) was chosen to identify key driver constructs, as well as to test the relationships among variables. The reason for choosing PLS-SEM is that 'PLS-SEM enables estimations of complex cause-effect relationships between constructs' (Kristensen 2016, p.43) and it can be used when the sample size population is relatively low (Hair, Ringle and Sarstedt 2011, p.145). Therefore, this study applied the rules of thumb for model evaluation outlined by Hair et al. (2011, p.145), which divides the analysis into two stages: formative measurement models and structural model. 


\begin{tabular}{|c|c|c|c|c|c|c|c|}
\hline \multicolumn{8}{|c|}{ Behavioural factors } \\
\hline $\begin{array}{l}\text { Perceived } \\
\text { Usefulness }\end{array}$ & $\begin{array}{l}\text { Perceived } \\
\text { uncertainty }\end{array}$ & Impulsiveness & Effort expectancy & Attitudes & $\begin{array}{l}\text { Perceived } \\
\text { asset }\end{array}$ & $\begin{array}{l}\text { Perceived } \\
\text { safety }\end{array}$ & $\begin{array}{l}\text { Perceived } \\
\text { enjoyment/ }\end{array}$ \\
\hline $\begin{array}{c}\text { Perceived ease of } \\
\text { use }\end{array}$ & Perceived value & $\begin{array}{l}\text { Consumers' } \\
\text { lifestyle }\end{array}$ & Perceived cost & Familiarity & $\begin{array}{l}\text { Behavioural } \\
\text { intention }\end{array}$ & $\begin{array}{l}\text { Performance } \\
\text { expectancy }\end{array}$ & $\begin{array}{c}\text { Perceived } \\
\text { behavioral control }\end{array}$ \\
\hline $\begin{array}{l}\text { Perceived } \\
\text { entitativity }\end{array}$ & Complexity & $\begin{array}{l}\text { Perceived } \\
\text { financial } \\
\text { resources }\end{array}$ & Compatibility & $\begin{array}{c}\text { Perceived } \\
\text { security levels }\end{array}$ & $\begin{array}{l}\text { Perceived } \\
\text { mobility }\end{array}$ & Privacy risk & $\begin{array}{c}\text { Users' awareness / } \\
\text { informal learning }\end{array}$ \\
\hline Perceived risk & User satisfaction & $\begin{array}{l}\text { Perceived } \\
\text { convenience }\end{array}$ & $\begin{array}{l}\text { Consumers' } \\
\text { willingness }\end{array}$ & $\begin{array}{l}\text { Perceived } \\
\text { reputation }\end{array}$ & $\begin{array}{c}\text { Perceived } \\
\text { Information } \\
\text { quality }\end{array}$ & Find Policies & $\begin{array}{l}\text { Mobile Payment } \\
\text { Experience / MP } \\
\text { knowledge/ }\end{array}$ \\
\hline Subjective norm & Flow & $\begin{array}{c}\text { Lack of } \\
\text { dependencies }\end{array}$ & $\begin{array}{l}\text { Perceived service } \\
\text { quality }\end{array}$ & Self-efficacy & $\begin{array}{l}\text { Perceived } \\
\text { system } \\
\text { quality }\end{array}$ & $\begin{array}{c}\text { Pre-purchase } \\
\text { anxiety }\end{array}$ & $\begin{array}{l}\text { Perceived benefit / } \\
\text { relative advantage }\end{array}$ \\
\hline $\begin{array}{c}\text { Perceived } \\
\text { expressiveness }\end{array}$ & Habit & Price Value & Attractiveness & benevolence & Integrity & Trialability & Social influence \\
\hline Utility & $\begin{array}{l}\text { Information } \\
\text { search }\end{array}$ & Interaction & Word of mouth & Social image & $\begin{array}{l}\text { Reference } \\
\text { groups }\end{array}$ & Exposure & Hedonic motivation \\
\hline
\end{tabular}

\begin{tabular}{|c|c|c|c|}
\hline \multicolumn{3}{|c|}{ Technological factors } \\
\hline $\begin{array}{c}\text { Device- } \\
\text { design } \\
\text { suitability }\end{array}$ & Ubiquity & $\begin{array}{c}\text { Fingerprint } \\
\text { recognition } \\
\text { technology }\end{array}$ & $\begin{array}{c}\text { Use of } \\
\text { PIN }\end{array}$ \\
\hline
\end{tabular}

\begin{tabular}{|c|c|c|l|c|}
\hline \multicolumn{5}{|c|}{ Personal factors } \\
\hline Age & Gender & Income & Ethnicity & Education \\
\hline $\begin{array}{c}\text { Marital } \\
\text { status }\end{array}$ & $\begin{array}{c}\text { Users' } \\
\text { characteri } \\
\text { stics }\end{array}$ & Occupation & Location & $\begin{array}{c}\text { Digital } \\
\text { lifestyle }\end{array}$ \\
\hline
\end{tabular}

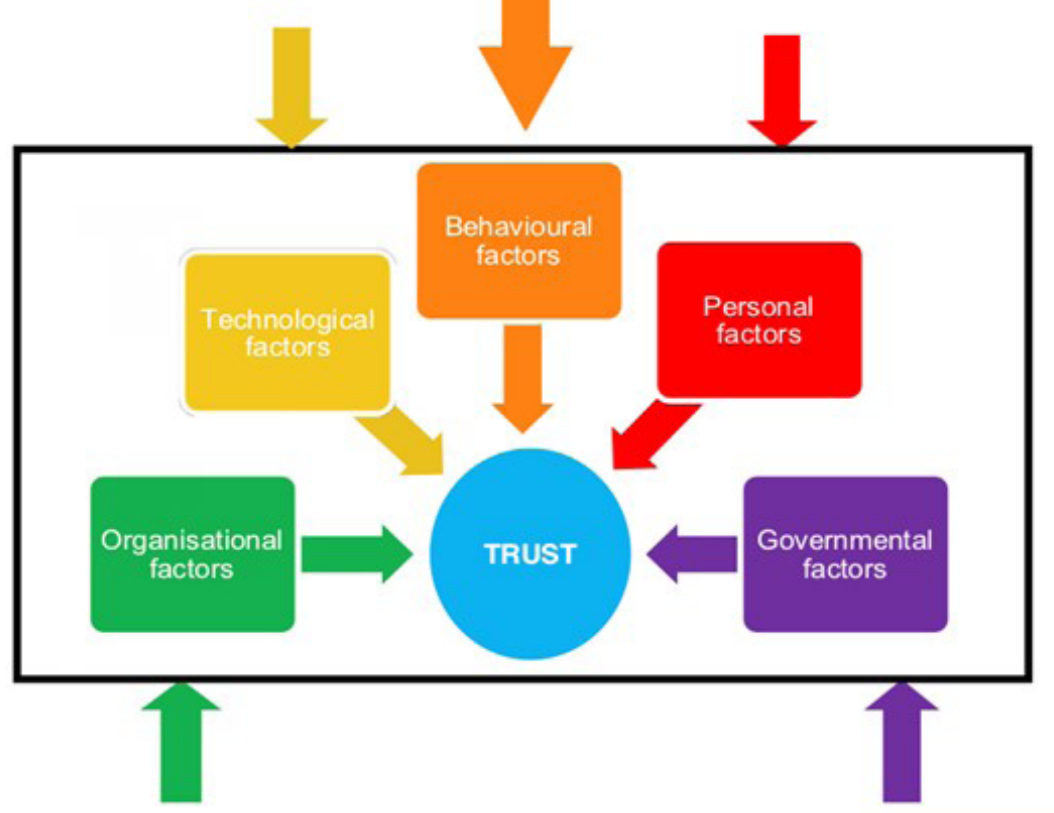

\begin{tabular}{|c|c|c|c|c|c|}
\hline \multicolumn{6}{|c|}{ Organisational factors } \\
\hline Transparency & $\begin{array}{c}\text { Providers' } \\
\text { trustworthiness }\end{array}$ & Conflicts & $\begin{array}{l}\text { Environmental } \\
\text { risk }\end{array}$ & Scale & Switching costs \\
\hline $\begin{array}{c}\text { Environmental } \\
\text { factors }\end{array}$ & $\begin{array}{l}\text { Development of } \\
\text { new products }\end{array}$ & $\begin{array}{l}\text { Trusted } \\
\text { Service } \\
\text { Manager } \\
\text { (TSM) }\end{array}$ & $\begin{array}{c}\text { Network } \\
\text { externalities }\end{array}$ & Innovativeness & $\begin{array}{c}\text { Inter- } \\
\text { organisational } \\
\text { factors }\end{array}$ \\
\hline $\begin{array}{l}\text { Situational } \\
\text { factors }\end{array}$ & $\begin{array}{l}\text { M Openness to } \\
\text { third parties }\end{array}$ & $\begin{array}{c}\text { service } \\
\text { availability }\end{array}$ & Involvement & $\begin{array}{l}\text { Facilitating } \\
\text { conditions }\end{array}$ & $\begin{array}{l}\text { Structural } \\
\text { assurance }\end{array}$ \\
\hline $\begin{array}{l}\text { Assessment of } \\
\text { the functional } \\
\text { reliability of MPS }\end{array}$ & Demand factors & $\begin{array}{c}\text { Strategic } \\
\text { objectives and } \\
\text { interests }\end{array}$ & $\begin{array}{l}\text { Maintaining a } \\
\text { relationship } \\
\text { with customers }\end{array}$ & Enticing promises & $\begin{array}{c}\text { Easy of Issuing and } \\
\text { distributing } \\
\text { solutions }\end{array}$ \\
\hline $\begin{array}{l}\text { Socio-economic } \\
\text { sector }\end{array}$ & $\begin{array}{c}\text { Company's } \\
\text { number of } \\
\text { workers }\end{array}$ & $\begin{array}{l}\text { Company's } \\
\text { income }\end{array}$ & Sales channels & $\begin{array}{c}\text { Payment } \\
\text { system's provider }\end{array}$ & $\begin{array}{c}\text { Typology of } \\
\text { payment systems } \\
\text { approached }\end{array}$ \\
\hline Fast transactions & $\begin{array}{l}\text { Electronic } \\
\text { readiness }\end{array}$ & $\begin{array}{c}\text { Additional } \\
\text { values of NFC } \\
\text { mobile } \\
\text { payment }\end{array}$ & $\begin{array}{l}\text { Absorptive } \\
\text { capacity }\end{array}$ & $\begin{array}{c}\text { Mobile } \\
\text { advertisement } \\
\text { effect }\end{array}$ & $\begin{array}{l}\text { Role in the } \\
\text { company }\end{array}$ \\
\hline
\end{tabular}

Governance issues / policies

Figure 1. Proposed Conceptual Research Framework 


\section{Formative measurement models}

The significance of the formative indicators (weight and loading) was assessed by using the evaluation of formative measurement models suggested by Hair, Ringle and Sarstedt (2011, p.146). According to Hair, Ringle and Sarstedt (2011, p.145), in order to evaluate the formative measurement models, there is a need to 'examine each indicator's weight (relative importance) and loading (absolute importance) to assess their significance'. The reason for measuring the indicators is that 'when both weight and loading are nonsignificant, there is no empirical support for the indicator's relevance in providing content to the formative index' (Cenfetelli and Bassellier 2009 cited in Hair 2011, p.146). In addition, Hair, Ringle and Sarstedt (2011 cited in Xin 2013, p.24) suggested that 'if all indicators' weights are significant, there is empirical support to keep all the indicators'.

In this regard, the research results pointed out that not all indicators' weights are significant (Appendix 1A), which means that there is a need to eliminate these indicators. In addition, Hair et al. (2013 cited in Shuhaiber 2016, p.149) suggested that 'indicators with outer loading above 0.7 should be retained, whereas indicators with outer loading between 0.4 and 0.7 should be considered for removal'. Furthermore, 'indicators with very low outer loadings (below 0.4) should be always eliminated from scale' (Hair, Ringle and Sarstedt 2011, Hulland 1999, Wong 2013 cited in Shuhaiber 2016, p.149). Therefore, the indicators of personal factors - income (PIN), behavioural factors (BH_3) and technological factors (TECH_4) were eliminated from the scale as shown in Appendix 1B.

Another relevant aspect of formative model evaluation is to examine the multicollinearity among latent variables in order to test if two indicators are highly correlated. In addition to that, in order to determine redundancy of information, 'researchers should examine the degree of multicollinearity in the formative indicators' (Cassel, Hackl and Westlund 1999; Diamantopoulos and Winklhofer 2001; Grewal, Cote and Baumgartner 2004 cited in Hair, Ringle and Sarstedt 2011, p.146). Multicollinearity among latent are assessed through the Variance Inflated Factor (VIF) and it 'is an important issue in assessing formative measures because of the potential for unstable indicator weights' (Cenfetelli and Bassellier 2009 cited in Hair et al. 2012, p.424). Hair, Ringle and Sarstedt (2011, p.145) suggested that VIF value should be less than 5. In this sense, after eliminating the negative values of the indicators' weight and loading, all VIF values were under 5 (Appendix 1C), which indicate that multicollinearity is not a problem with the formative indicators.

\section{Structural Model}

Hair, Ringle and Sarstedt (2011, p.145) pointed out that the 'primary evaluation criteria for structural model are the $\mathrm{R}^{2}$ measures and the level and significance of the path coefficients'. In addition the same authors suggested to use the Stone-Geisser's Q2 (Geisser 1974; Stone 1974 cited in Hair, Ringle and Sarstedt 2011, p.145) for data prediction.

\section{Coefficient of determination $\left(R^{2}\right.$ value $)$}

The first step for inner model assessment is to find the coefficient of determination, or $\mathrm{R}^{2}$ value, which 'represents the amount of explained variance of each endogenous latent variable' (Hair et al. 2012, p.426). Problems involving 'high collinearity in PLS-SEM can be seen from a high R-square $\left(\mathrm{R}^{2}\right)$ value' (Latan and Ramil 2013, p.9). $\mathrm{R}^{2}$ values can be divided into three categories in the structural model: substantial, moderate and weak, with values of $0.75,0.50$ and 0.25 respectively. It is worth mentioning that Hair, Ringle and Sarstedt (2011, p.147) suggested that 'whereas $\mathrm{R}^{2}$ results of 0.20 
are considered high in disciplines such as consumer behaviour, $\mathrm{R}^{2}$ values of 0.75 would be perceived as high in success driver studies'. In this sense, Figure 2 and 3 shows $\mathrm{R}^{2}$ values before and after eliminating negative values of the indicators' weights and loadings (Appendices 1A and 1B):

The results pointed out that the structural model has a moderate level of $\mathrm{R}^{2}$ values $(0.493)$. This suggests that for the proposed conceptual model, $49.3 \%$ variance of the endogenous variable (consumers' trust) could be explained by the exogenous variables (organisational, technological, behavioural, personal and governmental).

\section{Path coefficients}

The second step to the structural model assessment is to test the strength of the relationships among variables by computing the empirical $t$ values and $p$ values for all structural path coefficients. The bootstrapping procedure was used to test the significance of formative indicators' coefficients. The reason to use a bootstrapping procedure is that the 'PLS-SEM does not presume that the data are normally distributed' (Hair, Ringle and Sarstedt 2011, p.148). In this context, the bootstrapping procedure was applied for the significance of the path coefficient with two-tails significant level of $5 \%$ or a t value of 1.96 (Chin 1998b; Chin 2010, Henseler et al. 2009; Latan and Ghozali 2012a cited in Latan and Ramil 2013 p.20). Table 7 shows the result of the bootstrapping procedure:

Table 7. Path coefficient

\begin{tabular}{|c|c|c|c|c|c|c|}
\hline & $\begin{array}{c}\text { T } \\
\text { Statistics }\end{array}$ & Critical value & $\begin{array}{c}\text { Statistically } \\
\text { significance } \\
(\mathrm{t}>1.96)\end{array}$ & P Values & Critical value & $\begin{array}{c}\text { Statistically } \\
\text { significance } \\
(p<0.05)\end{array}$ \\
\hline $\begin{array}{l}\text { BEHAVIOURAL FACTORS } \\
\rightarrow \text { TRUST }\end{array}$ & 6.146 & 1.96 & YES & 0.000 & 0.05 & YES \\
\hline $\begin{array}{l}\text { GOVERNMENTAL FACTORS } \\
\rightarrow \text { TRUST }\end{array}$ & 1.303 & 1.96 & NO & 0.193 & 0.05 & NO \\
\hline $\begin{array}{l}\text { ORGANISATIONAL FACTORS } \\
\rightarrow \text { TRUST }\end{array}$ & 2.271 & 1.96 & YES & 0.023 & 0.05 & YES \\
\hline $\begin{array}{l}\text { PERSONAL FACTORS } \\
\rightarrow \text { TRUST }\end{array}$ & 0.061 & 1.96 & NO & 0.951 & 0.05 & NO \\
\hline $\begin{array}{l}\text { TECHNOLOGICAL FACTORS } \\
\rightarrow \text { TRUST }\end{array}$ & 0.651 & 1.96 & NO & 0.515 & 0.05 & NO \\
\hline
\end{tabular}

The results showed that there is a strong relationship between behavioural factors and trust $(t=6.146, p=0.000)$. A significant relationship is also verified between organisational factors and trust $(\mathrm{t}=2.271, \mathrm{p}=0.023)$. However, the relationships between governmental factors and trust $(\mathrm{t}=1.303$, $\mathrm{p}=0.193)$, personal factors and trust $(\mathrm{t}=0.061, \mathrm{p}=0.951)$ and technological factors and trust $(\mathrm{t}=0.651$, $\mathrm{p}=0.515)$ are not significant in so far as $t$ values are smaller than the critical values (1.96) and $p$ values are bigger that 0.05 respectively.

\section{Blindfolding and predictive relevance $\left(Q^{2}\right)$}

In order to evaluate the magnitude of $\mathrm{R}^{2}$ values with predictive accuracy, this study used StoneGeisser's Q2 (Geisser 1974; Stone 1974 cited in Hair, Ringle and Sarstedt 2011, p.145) in order to assess the model's capability to predict. The blindfolding procedure was used to measure the 


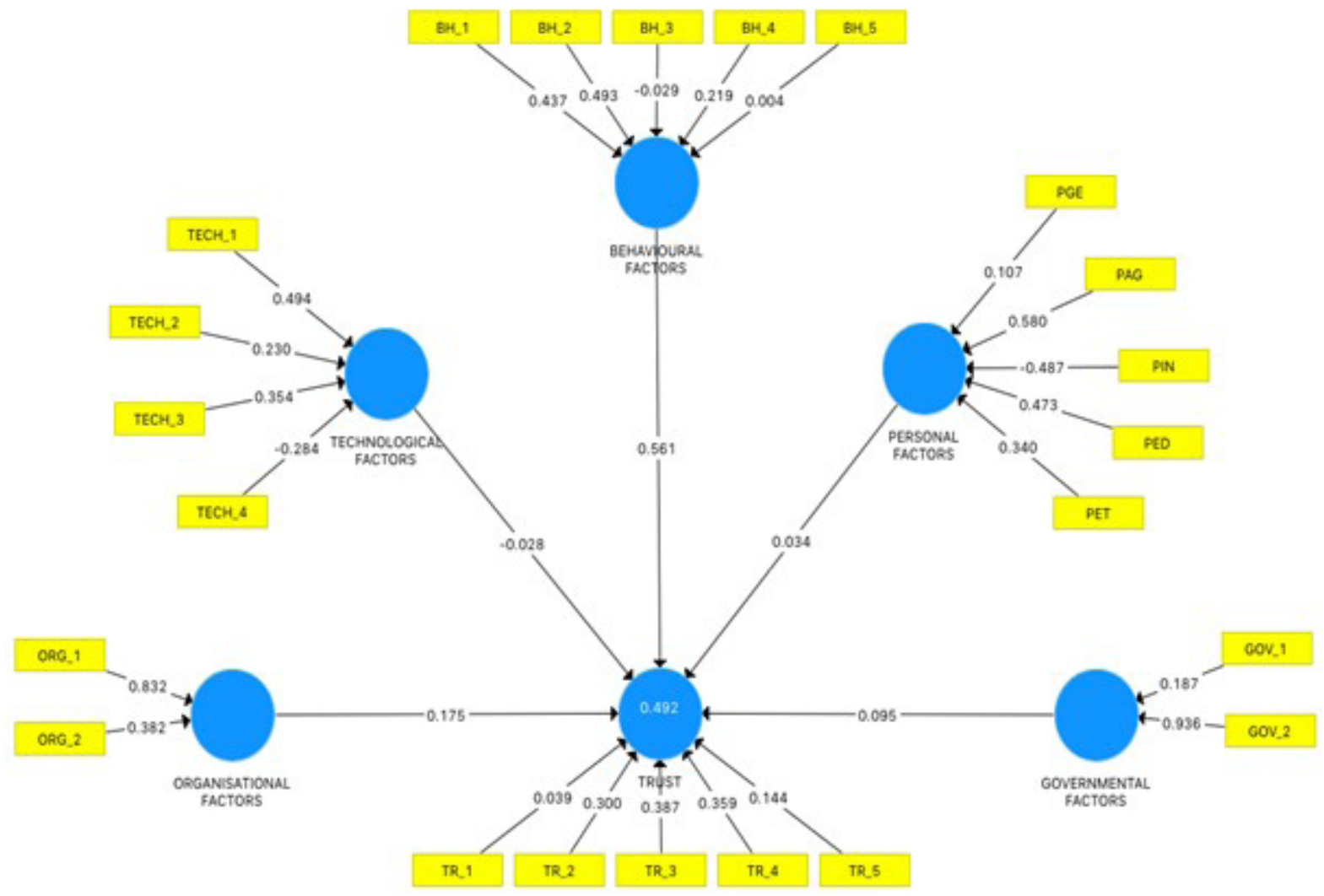

Figure 2. $\mathrm{R}^{2}$ values before eliminating negative indicators

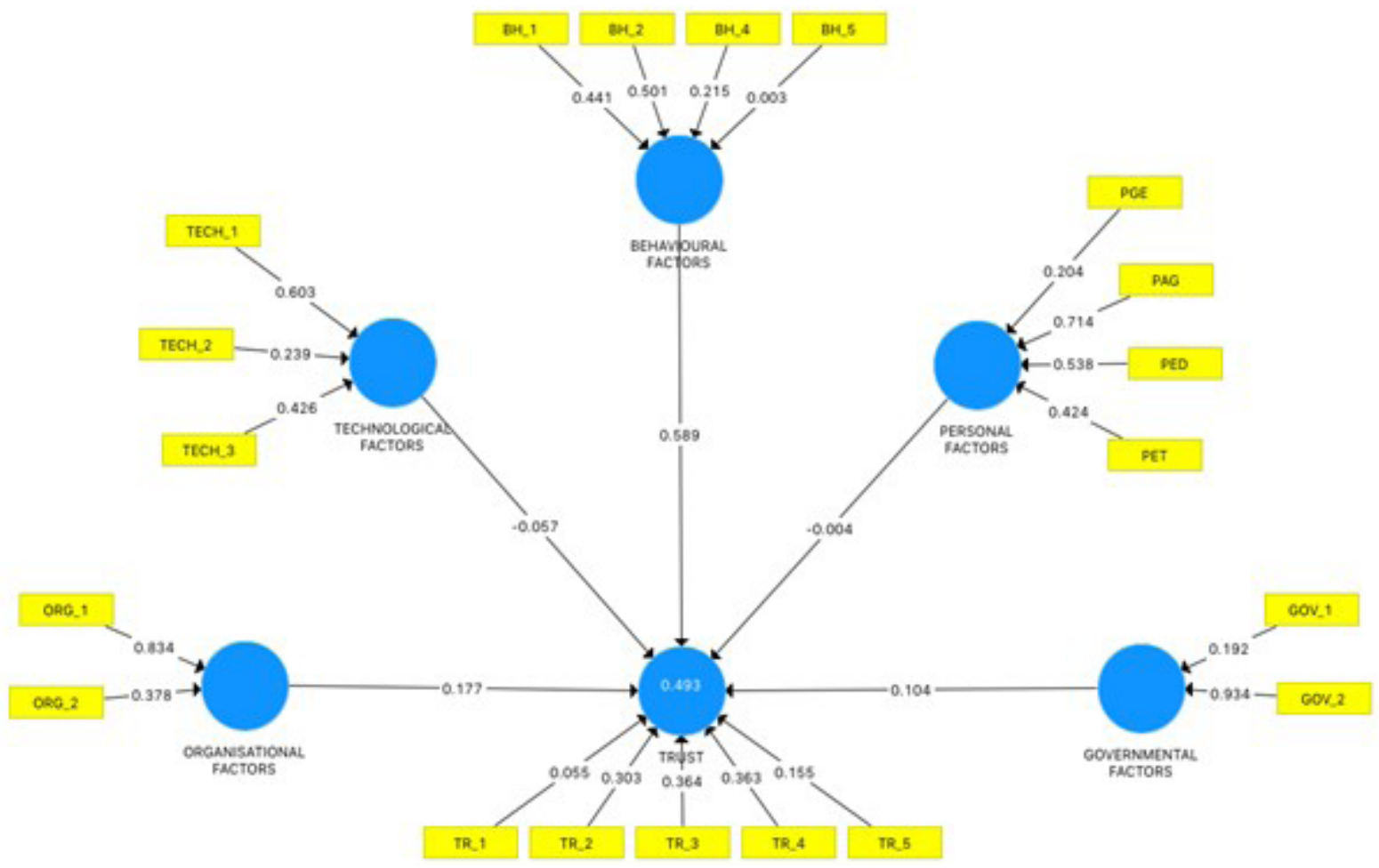

Figure 3. $R^{2}$ values after eliminating negative indicators 
predictive relevance of each endogenous latent construct's indicators. It postulates that 'resulting $\mathrm{Q}^{2}$ values of larger than zero indicate that the exogenous constructs have predictive relevance for the endogenous construct under consideration' (Hair, Ringle and Sarstedt 2011, p.145). In addition, exogenous constructs have a small, medium or large predictive relevance if $\mathrm{Q}^{2}$ values are $0.02,0.15$ or 0.35 respectively. It is worth mentioning that SSO represents the sum of the square observations and SSE represents the sum of prediction errors. Table 8 illustrates the $\mathrm{Q}^{2}$ value:

Table 8. $Q^{2}$ value

\begin{tabular}{lccc}
\hline & $\begin{array}{c}\text { Sum of the square observations } \\
\text { (SSO) }\end{array}$ & $\begin{array}{c}\text { Squared prediction errors (SSE) } \\
\mathbf{Q}^{2} \text { (=1-SSE/SSO) }\end{array}$ \\
\hline BEHAVIOURAL FACTORS & 800.000 & 800.000 \\
GOVERNMENTAL FACTORS & 400.000 & 400.000 \\
ORGANISATIONAL FACTORS & 400.000 & 400.000 \\
PERSONAL FACTORS & 800.000 & 800.000 \\
TECHNOLOGICAL FACTORS & 600.000 & 600.000 \\
TRUST & $1,000.000$ & 766.406 & $\mathbf{0 . 2 3 4}$ \\
\hline
\end{tabular}

The analysis of the construct cross-validated redundancy indicates that the $\mathrm{Q}^{2}$ value is 0.234 , which means that exogenous constructs has a medium predictive relevance $(0.15)$ for endogenous construct under consideration.

The next chapter discusses the research findings as well as it provides a comparison with previous studies in the MPS field.

\section{RESEARCH FINDINGS AND DISCUSSION}

The findings of this study revealed that trust is an essential factor on MPS adoption. The majority of respondents of the survey believe that trust has a direct impact on consumers' intention to adopt the MPS in Australia. This result is consistent with previous MPS studies conducted in other countries (Abidin et al. 2017; Hampshire 2016; Cao, Dang and Nguyen 2016; Duane, O'Reilly and Andreev 2014; Xin 2013), which highlighted that trust is a pivotal factor on consumers' intention to adopt the MPS and that building consumers' trust is a key factor to the success of MPS. On the flip side, this outcome contradicted the findings of William et al $(2017$, p.7) who found that trust has not significant impact on consumers' intentions to use MPS within the Middle East and Africa block. In addition, Pham and Ho (2015, p.168) found that trust have an insignificant effect on the consumers' intention to adopt the NFC-based mobile payments in Taiwan.

The review of literature pointed out 110 factors that were tested alongside with trust in order to investigate their impact on consumers' intention to adopt the MPS. In order to summarise, and simplify, the different viewpoints on the subject-matter, this study proposed a research framework that has divided those factors into 5 distinct categories: personal factors, behavioural factors, organisational factors, technological factors, and governmental factors.

The results of the PLS-SEM analysis indicated that behavioural factors, which represent users' perception of the benefits and risks of using their smartphones for making payments, are the most important factors for Australian consumers in order to adopt the MPS. . The findings indicated that 
there is a strong positive relationship between behavioural factors and consumers' trust in mobile payment, which suggests that behavioural factors have impact on consumers' trust. The results of the coefficient of determination $\left(\mathrm{R}^{2}\right.$ value) and path coefficient (t-value and $\mathrm{p}$-value) support this statement.

With regards to organisational factors, which refer to all service providers, financial institutions and vendors across the country, this study found a positive relationship between organisational factors and consumers' trust in mobile payment. The findings also indicated that Australian consumers would adopt the MPS if they had the feeling that the service provided by organisations is trustworthy. This confirms previous studies (Lwoga \& Lwoga 2017; Shuhaiber 2016; Zhou 2013; Xin 2013) in which the influence of the organisational factors on consumers' trust was tested through a range of sub factors.

Surprisingly, a negative relationship between technological factors and consumers' trust in mobile payment was found in this study. The findings suggested that technological factors have no significant impact on consumers' trust. This result contradicts some other studies (Shuhaiber 2016; Yan and Yang 2015) which suggest that there is a positive relationship between the technological factors and trust of consumers in mobile payment. A plausible reason for this result is that mobile payment is a new feature of the payment market and it is still an ongoing process of implementation in Australia (Doyle et al. 2017, p.63), with around 1\% of the population using this method for making payments.

In addition to that, the results pointed out that there is a negative relationship between governmental factors and consumers' trust in mobile payment, which suggests that governmental factors have no impact on consumers' trust. Surprisingly, this result contrasts with de Reuver et al. (2015) who found that governments play a major role in mobile payment projects. Furthermore, Veijalainen (2006 cited in Vasileiadis 2014, p.182), highlighted that 'governmental institutions play a fundamental role in establishing legislation and standards of services and they should constantly adapt it to the market development and new technologies in order to protect mobile consumers. A plausible explanation for this result is that Australian consumers might have a little knowledge of how often the government has interfered or has changed the policies on MPS sector over the last years.

The assessment of the predictive accuracy of the research model was determined by the results of $\mathrm{R}^{2}$ and Stone-Geisser's $\mathrm{Q}^{2}$. In relation to the factors that have impact on consumers' trust. The findings suggested that the exogenous variables have a moderate level of impact on the endogenous variable $\left(\mathrm{R}^{2}=0.493\right)$. In other words, the external variables (organisational, technological, behavioural, personal and governmental) have a moderate level of impact on the internal variable (consumers' trust). This result indicates that $49.3 \%$ of the variance of consumers' trust could be explained by the influence of the external factors have on it. In addition, the result of the Stone-Geisser's $\mathrm{Q}^{2}$ value (0.234) suggested that the exogenous variables have a medium predictive relevance for consumers' trust under consideration. In other words, the external variables analysed in this study have a medium relevant impact on consumers' trust.

Thus, organisational factors and behavioural factors have impact on consumers' trust and this has influence on MPS adoption. Removing these factors would increase $\mathrm{R}^{2}$ values of the other factors (personal, technological and governmental), which may increase the impact on consumers' trust. However, the opposing case was not verified. 
To sum it all up, organisational factors and behavioural factors are the main drivers for building consumers' trust in the MPS. The constructs of personal factors, technological factors and governmental factors have no significant impact on consumers' trust and they need to be reconsidered in the model in so far as they have a little contribution to the variance on consumers' trust.

\section{Summary of findings in this research}

In the previous sections, the results of this research pointed out that the factors that have influence on consumers' trust in Australian. The findings indicated that behavioural factors and organisational factors have impact on consumers' trust and this, as a result, has impact on MPS adoption. On the other hand, technological factors, personal factors and governmental factors have no impact on consumers' trust. Figure 4 summarises the findings of this research.

\begin{tabular}{|c|c|c|c|c|c|c|c|}
\hline \multicolumn{8}{|c|}{ Behavioural factors } \\
\hline $\begin{array}{l}\text { Perceived } \\
\text { Usefulness }\end{array}$ & $\begin{array}{l}\text { Perceived } \\
\text { uncertainty }\end{array}$ & Impulsiveness & Effort expectancy & Attitudes & $\begin{array}{l}\text { Perceived } \\
\text { asset }\end{array}$ & $\begin{array}{l}\text { Perceived } \\
\text { safety }\end{array}$ & $\begin{array}{l}\text { Perceived } \\
\text { enjoyment }\end{array}$ \\
\hline $\begin{array}{c}\text { Perceived ease of } \\
\text { use }\end{array}$ & Perceived value & $\begin{array}{c}\text { Consumers' } \\
\text { lifestyle }\end{array}$ & Perceived cost & Familiarity & $\begin{array}{l}\text { Behavioural } \\
\text { intention }\end{array}$ & $\begin{array}{c}\text { Performance } \\
\text { expectancy }\end{array}$ & $\begin{array}{c}\text { Perceived } \\
\text { behavioral control }\end{array}$ \\
\hline $\begin{array}{l}\text { Perceived } \\
\text { entitativity }\end{array}$ & Complexity & $\begin{array}{l}\text { Perceived } \\
\text { financial } \\
\text { resources }\end{array}$ & Compatibility & $\begin{array}{c}\text { Perceived } \\
\text { security levels }\end{array}$ & $\begin{array}{l}\text { Perceived } \\
\text { mobility }\end{array}$ & Privacy risk & $\begin{array}{l}\text { Users' awareness } \\
\text { informal learning }\end{array}$ \\
\hline Perceived risk & User satisfaction & $\begin{array}{l}\text { Perceived } \\
\text { convenience }\end{array}$ & $\begin{array}{l}\text { Consumers } \\
\text { willingness }\end{array}$ & $\begin{array}{l}\text { Perceived } \\
\text { reputation }\end{array}$ & $\begin{array}{c}\text { Perceived } \\
\text { Information } \\
\text { quality }\end{array}$ & Find Policies & $\begin{array}{c}\text { Mobile Payment } \\
\text { Experience / MP } \\
\text { knowledge/ }\end{array}$ \\
\hline Subjective norm & Flow & $\begin{array}{c}\text { Lack of } \\
\text { dependencies }\end{array}$ & $\begin{array}{c}\text { Perceived service } \\
\text { quality }\end{array}$ & Self-efficacy & $\begin{array}{l}\text { Perceived } \\
\text { system } \\
\text { quality }\end{array}$ & $\begin{array}{c}\text { Pre-purchase } \\
\text { anxiety }\end{array}$ & $\begin{array}{l}\text { Perceived benefit / } \\
\text { relative advantage }\end{array}$ \\
\hline $\begin{array}{c}\text { Perceived } \\
\text { expressiveness }\end{array}$ & Habit & Price Value & Attractiveness & benevolence & Integrity & Trialability & Social influence \\
\hline Utility & $\begin{array}{l}\text { Information } \\
\text { search }\end{array}$ & Interaction & Word of mouth & Social image & $\begin{array}{l}\text { Reference } \\
\text { groups }\end{array}$ & Exposure & Hedonic motivation \\
\hline
\end{tabular}

\begin{tabular}{|c|c|c|c|}
\hline \multicolumn{4}{|c|}{ Technological factors } \\
\hline $\begin{array}{c}\text { Device- } \\
\text { design } \\
\text { suitability }\end{array}$ & Ubiquity & $\begin{array}{c}\text { Fingerprint } \\
\text { recognition } \\
\text { technology }\end{array}$ & $\begin{array}{c}\text { Use of } \\
\text { PIN }\end{array}$ \\
\hline
\end{tabular}

\begin{tabular}{|c|c|l|l|l|}
\hline \multicolumn{5}{|c|}{ Personal factors } \\
\hline Age & Gender & Income & Ethnicity & Education \\
\hline $\begin{array}{c}\text { Marital } \\
\text { status }\end{array}$ & $\begin{array}{c}\text { Users' } \\
\text { characteri } \\
\text { stics }\end{array}$ & Occupation & Location & $\begin{array}{c}\text { Digital } \\
\text { lifestyle }\end{array}$ \\
\hline
\end{tabular}

Figure 4. Summary of findings

\section{CONCLUSION}

The aim of this study was to examine the impact of consumers' trust on MPS adoption in Australia and build a framework based on the impact of Australian consumer's trust on mobile payment systems. In order to simplify the various studies conducted in MPS field between 2013 and 2017, this study summarised 110 factors that were tested with trust in different research models in only one single conceptual framework. This conceptual framework summarises these 110 factors in five distinct factors (organisational, technological, behavioural, personal and governmental). The aim to test the single conceptual framework was to comprehend which factors are more relevant for Australian consumers in order to gain their trust. 
The findings of this study were based on the answers of 200 respondents of the online questionnaire survey. The data was analysed by employing the statistical package for the social sciences (SPSS) program and the partial least square - structural equation modeling (PLS-SEM).

The results pointed out that trust is an essential factor for Australian consumers and it plays a pivotal role on MPS adoption. The majority of participants of the survey believe that trust has a direct impact on their intention to adopt the MPS in Australia.

The findings of study pointed out that behavioural factors and organisational factors have significant impact on consumers' trust, and this, as a consequence, have influence on MPS adoption. These findings are the new contribution and the primary knowledge of this research. Behavioural factors are related to the consumers' perception of the provided services or, in other words, the perception of the benefits and risks of using a new gadget or service. Organisations factors are represented by all service providers such as Australian banks, mobile network providers (Telstra, Optus etc.) and other companies (Apple, Google, Samsung, etc.) that have been investing and providing an electronic payment ecosystem to their customers.

On the other hand, technological factors, personal factors and governmental factors have no significant impact on consumers' trust.

\section{LIMITATIONS AND RECOMMENDATION FOR FURTHER RESEARCH}

There are some limitations in this study. First, this research is based on previous studies conducted from 2013 to 2017, which have indicated that trust and other factors have some influence on users' intention to adopt the MPS. Although, these factors were tested in different countries, it is not certain that these factors have the same relevance for Australian consumers. In addition, by testing a new research model, this study summarised and simplified other factors which could have some influence on the results.

Second, this study focused on Australian consumers 18 and over, which represents the minimum age for a primary account holder of a credit card, according to the Australia's big four banks analysed NAB (2017), ANZ (2017), CBA (2017) and Westpac (2017). This can have some implications on personal factors, due to the fact that people under 18 and as young as 16 years of age can be an additional cardholder and get the bills paid by their parents.

Third, the overrepresentation of female respondents might have created a bias in the analysis. As mobile payment users represent less than $1 \%$ of the population in Australia, any overrepresentation of one segment could have impact on the outcome of the analysis.

Future studies should focus on investigating the effect of culture on the intention to adopt the MPS in so far as this study has not found any research conducted between 2013 and 2017. In addition, the ethnicity of target population needs to be studied in so far as this research has found different outcome with previous studies. This can be done by comparing and contrasting results from different cultures, as well as people from different countries.

Furthermore, future studies should investigate the adoption of MPS from merchants' perspective in so far as this research found that only few studies have explored this topic.

Finally, despite this research has found that technological factors, personal factors and governmental factors have no significant impact on MPS, there is a need to compare and analyse 
in-depth these results with other countries in so far as the findings of this research contradicts other studies conducted in other countries.

\section{REFERENCES}

Abidin, WZ, Rivera, O, Maarop, N \& Hassan, NH 2017, Mobile payment framework for the unbanked Filipinos, paper presented at 2017 International Conference on Research and Innovation in Information Systems (ICRIIS) doi:10.1109/ICRIIS.2017.8002478

Australia and New Zealand Bank group (ANZ) 2017, Applying for a credit card, viewed 7 July 2017, https:// www.anz.com.au/personal/credit-cards/apply-card/

Australian Bureau of Statistics (ABS) 2016, Household Use of Information Technology, Australia, 2014-15, cat. no. 8146.0, in press.

Australian Payments Clearing Association (APCA) 2016, Towards the digital economy: milestones report, Fifth Report, media released April 2016, in press.

Australian Payments Clearing Association (APCA) 2016, Towards the digital economy: milestones report, Fifth Report, media released April 2016, in press.

Australian Payments Council (APC) 2015, Shaping the future of Australian Payments, in press.

Australian Payments Network (APN) 2017, Towards the digital economy - milestones report may 2017, in press.

Cao, TK, Dang, PL \& Nguyen, HA 2016, Predicting consumer intention to use mobile payment services: empirical evidence from Vietnam, International Journal of Marketing Studies, vol.8, no.1, pp.117-124. doi:10.5539/ijms.v8n1p117

Chen, X \& Li, S 2016, Understanding continuance intention of mobile payment services: an empirical study, Journal of Computer Information Systems, pp.1-12,doi:10.1080/08874417.2016.1180649

Chong, AYL 2013, Predicting m-commerce adoption determinants: a neural network approach, Expert Systems with Applications, vol.40, no.2, pp.523-530.

Commonwealth Bank of Australia (CBA) 2017, Credit card Application, viewed 7 July 2017, https://www. commbank.com.au/personal/apply-online/download-printed-forms/000-999.pdf

Dastan, I \& Gürler C 2016, Factors affecting the adoption of mobile payment systems: an Empirical Analysis, Emerging Markets Journal, vol.6, no.1, pp.17-24, doi:10.5195/emaj.2016.95

de Reuver, M, Verschuur, E, Nikayin, F, Cerpa, N \& Bouwman, H 2015, Collective action for mobile payment platforms: a case study on collaboration issues between banks and telecom operators, Electronic Commerce Research and Applications, vol.14, no.5, pp.331-344. doi:10.1016/j.elerap.2014.08.004

Doyle, MA, Fisher, C, Tellez, E \& Yadav, A 2017, How Australians pay: new survey evidence, RBA Bulletin, pp.59-66, in press.

Duane, A, O'Reilly, P \& Andreev, P 2014, Realising M-Payments: modelling consumers' willingness to M-pay using Smart Phones, Behaviour \& Information Technology, vol.33, no.4, pp.318-334. doi:10.1080/ 0144929X.2012.745608

Gao, L \& Waechter, KA 2015, Examining the role of initial trust in user adoption of mobile payment services: an empirical investigation, Information Systems Frontiers, pp.1-24. doi:10.1007/s10796-0159611-0. 
Gong, X, Zhang, KZ, Zhao, SJ \& Lee, MK 2016, The effects of cognitive and emotional trust on mobile payment adoption: a trust transfer perspective, paper presented at PACIS 2016 Proceedings, Paper 350. Retrieved from https://aisel.aisnet.org/pacis2016/350

Hair, JF, Ringle, CM and Sarstedt, M 2011, PLS-SEM: indeed a silver bullet. Journal of Marketing theory and Practice, vol. 19, n. 2, pp.139-152.

Hair, JF, Sarstedt, M, Ringle, CM \& Mena, JA 2012, An assessment of the use of partial least squares structural equation modeling in marketing research. Journal of the academy of marketing science, vol.40, n.3, pp.414-433.

Hampshire, C 2016, 'Exploring UK consumer perceptions of mobile payments using smart phones and contactless consumer devices through an extended technology adoption model', PhD thesis, University of Chester.

Hillman, S, Neustaedter, C, Oduor, E \& Pang, C 2014, User challenges and successes with mobile payment services in North America, Refereed papers from the 16th International Conference on Humancomputer Interaction with Mobile Devices \& Services, Simon Fraser University, Toronto, pp. 253-262. doi:10.1145/2628363.2628389.

Köster, A, Matt, C \& Hess, T 2016, Carefully choose your (payment) partner: how payment provider reputation influences m-commerce transactions, Electronic Commerce Research and Applications, vol. 15, pp. 26-37. doi:10.1016/j.elerap.2015.11.002.

Kristensen, SM 2016, 'Understanding factors influencing Danish consumers' intention to use mobile payment at point-of-sale', MSc thesis, Aarhus University.

Latan \& Ramil 2013, The results of partial least squares-structural equation modelling analyses (PLS-SEM)

Liébana-Cabanillas, F, Sánchez-Fernández, J \& Muñoz-Leiva, F 2014, Antecedents of the adoption of the new mobile payment systems: the moderating effect of age, Computers in Human Behavior, vol.35, pp.464-478. doi:10.1016/j.chb.2014.03.022

Liébana-Cabanillas, F, Sánchez-Fernández, J \& Muñoz-Leiva, F 2014, Role of gender on acceptance of mobile payment, Industrial Management \& Data Systems, vol.114, no.2, pp.220-240. doi:10.1108/IMDS03-2013-0137

Lwoga, E \& Lwoga, N 2017, User acceptance of mobile payment: the effects of user-centric security, system characteristics and gender, The Electronic Journal Information Systems in Developing Countries, vol. 81, no. 3, pp. 1-24. doi:10.1002/j.1681-4835.2017.tb00595.x

Mahad, M, Mohtar, S \& Othman, AA 2015, The effect of perceived trust of mobile banking services in Malaysia, International Academic Research Journal of Business and Technology, vol.1, no.7, pp.1-7, in press.

National Australia Bank Limited (NAB) 2017, Apply for a credit card, viewed 7 July 2017, https://www.nab. com.au/personal/banking/credit-cards/apply-for-a-credit-card

Pachare, SM 2016, Demonetization: unpacking the digital wallets, We'Ken - International Journal of Basic and Applied Sciences, vol.1, no.4, pp.180-183.

Pham, TTT \& Ho, JC 2015, The effects of product-related, personal-related factors and attractiveness of alternatives on consumer adoption of NFC-based mobile payments, Technology in Society, vol.43, pp.159-172. doi: 10.1016/j.techsoc.2015.05.004

Shaw, N 2014, The mediating influence of trust in the adoption of the mobile wallet, Journal of Retailing and Consumer Services, vol.21, no.4, pp. 449-459, doi:10.1016/j.jretconser.2014.03.008. 
Shuhaiber, A 2016, 'Factors influencing consumer trust in mobile payments in the United Arab Emirates', $\mathrm{PhD}$ thesis, Victory University of Wellington.

Slade, EL, Dwivedi, YK, Piercy, NC \& Williams, MD 2015, Modeling consumers' adoption intentions of remote mobile payments in the United Kingdom: extending UTAUT with innovativeness, risk, and trust, Psychology \& Marketing, vol.32, no.8, pp.860-873. doi:10.1002/mar.20823

Teoh, WMY, Chong, SC, Lin, B \& Chua, JW 2013, Factors affecting consumers' perception of electronic payment: an empirical analysis, Internet Research, vol.3, no.4, pp.465-485, doi:10.1504/ IJMC.2015.070961

Vasileiadis, A 2014, Security concerns and trust in the adoption of m-commerce, Social Technologies, vol.4, no.1, pp.179-191. . doi:10.13165/ST-14-4-1-12

Wang, S, Fan, J \& Zhang, M 2015, An empirical study on the impact of perceived benefit, risk and trust on e-payment adoption: comparing Quick Pay and Union Pay in China, paper presented at 7th International Conference on Intelligent Human-Machine Systems and Cybernetics 2015, vol. 2, pp. 198-202, Retrieved from https://ieeexplore.ieee.org/abstract/document/7334950

Westpac Banking Corporation 2017, Credit card application, viewed 7 July 2017, https://www.westpac.com. au/docs/pdf/pb/SIA_Application_Form.pdf

Williams, MD, Roderick, S, Davies, GH \& Clement, M 2017, Risk, trust, and compatibility as antecedents of mobile payment adoption, Refereed papers from the Twenty-third Americas Conference on Information Systems, pp.1-10, Boston

Xin, H 2013, 'Exploring the influence of trust and culture on mobile payment adoption', MBIS thesis, Auckland University of Technology. doi: 10.1080/08874417.2015.11645781

Xin, H, Techatassanasoontorn, AA \& Tan, FB 2013, Exploring the influence of trust on mobile payment adoption, Pacific Asia Conference on Information Systems (PACIS 2013), paper 143, pp. 1-17.

Yan, H \& Pan, K 2015, Examining mobile payment user adoption from the perspective of trust transfer, International Journal of Networking and Virtual Organisations, vol.15, no.2-3, pp.136-151. doi: 10.1504/ IJNVO.2015.070423

Yan, H \& Yang, Z 2015, Examining mobile payment user adoption from the perspective of trust, International Journal of u-and e-Service, Science and Technology, vol.8, no.1, pp.117-130. doi: 10.14257/ ijunesst.2015.8.1.11

Yoon, HS \& Occeña, LG 2015, Influencing factors of trust in consumer-to-consumer electronic commerce with gender and age, International Journal of Information Management, vol.35, no.3, pp.352-363, doi:10.1016/j.ijinfomgt.2015.02.003

Zhou, T 2013, An empirical examination of continuance intention of mobile payment services, Decision Support Systems, vol.54, no.2, pp.1085-1091. doi:10.1016/j.dss.2012.10.034 


\section{APPENDIX 1: PLS-SEM ANALYSIS}

A) Weights and Loadings (Before eliminating negative values)

\begin{tabular}{|c|c|c|c|c|}
\hline Constructs & Abbrev. & items & Weights & Loadings \\
\hline \multirow{5}{*}{ Personal factors } & PGE & Personal Characteristics - Gender & 0.107 & 0.089 \\
\hline & PAG & Personal Characteristics - Age & 0.580 & 0.621 \\
\hline & PIN & Personal Characteristics - Income & -0.487 & -0.570 \\
\hline & PED & Personal Characteristics - Education & 0.473 & 0.446 \\
\hline & PET & Personal Characteristics - Ethnicity & 0.340 & 0.415 \\
\hline \multirow{5}{*}{ Trust } & TR_1 & Trust is an essential factor in mobile payment adoption & 0.039 & 0.310 \\
\hline & TR_2 & $\begin{array}{l}\text { I would trust that my personal information is safe (meaning } \\
\text { secure and confidential) when making a mobile payment }\end{array}$ & 0.300 & 0.776 \\
\hline & TR_3 & $\begin{array}{l}\text { I would trust in a mobile payment service provided by an } \\
\text { Australian Bank (e.g. CBA, NAB, ANZ, Westpac, etc.) }\end{array}$ & 0.387 & 0.865 \\
\hline & TR_4 & $\begin{array}{l}\text { I would trust in a mobile payment service provided by my } \\
\text { mobile network operator (e.g. Telstra, Optus, Vodafone, etc.) }\end{array}$ & 0.359 & 0.880 \\
\hline & TR_5 & $\begin{array}{l}\text { I would trust in a mobile payment service provided by } \\
\text { companies other than a bank or mobile network operator (e.g. } \\
\text { ApplePay, SamsungPay, PayPal etc.) }\end{array}$ & 0.144 & 0.729 \\
\hline \multirow{5}{*}{ Behavioural factors } & BH_1 & I believe that using a mobile device to make a payment is easy & 0.437 & 0.880 \\
\hline & BH_2 & $\begin{array}{l}\text { I believe that mobile payment systems are useful if they } \\
\text { provide a faster service than other types of payment. }\end{array}$ & 0.493 & 0.918 \\
\hline & BH_3 & $\begin{array}{l}\text { I believe that using a mobile device to pay bills is riskier than } \\
\text { other payment systems (e.g. cash, cards, etc.) }\end{array}$ & -0.029 & -0.230 \\
\hline & BH_4 & $\begin{array}{l}\text { I am going to use a mobile payment system if my close friends } \\
\text { or someone I trust are doing the same. }\end{array}$ & 0.219 & 0.705 \\
\hline & BH_5 & $\begin{array}{l}\text { Cost rather than security is important to me when it comes to } \\
\text { adopting a new payment system. }\end{array}$ & 0.004 & 0.199 \\
\hline \multirow{4}{*}{ Technological factors } & TECH_1 & I am familiar with using my smartphone for making payment & 0.494 & 0.854 \\
\hline & TECH_2 & How often do you change your smartphone? & 0.230 & 0.588 \\
\hline & TECH_3 & How often do you update software on your smartphone? & 0.354 & 0.731 \\
\hline & TECH_4 & $\begin{array}{l}\text { I do not or will not use a mobile payment system because I } \\
\text { have no knowledge on how to use my smartphone to pay my } \\
\text { bills }\end{array}$ & -0.284 & -0.647 \\
\hline \multirow{2}{*}{ Organisational factors } & ORG_1 & $\begin{array}{l}\text { I have been choosing my mobile service provider based on the } \\
\text { reputation that they have in the market. }\end{array}$ & 0.832 & 0.929 \\
\hline & ORG_2 & $\begin{array}{l}\text { I would consider using a mobile payment system if I feel that } \\
\text { the offered packaged benefits are greater than the risks }\end{array}$ & 0.382 & 0.595 \\
\hline \multirow[b]{2}{*}{ Governmental factors } & GOV_1 & $\begin{array}{l}\text { I feel that the Australian government has been changing the } \\
\text { policies in the mobile payment sector very often. }\end{array}$ & 0.187 & 0.423 \\
\hline & GOV_2 & $\begin{array}{l}\text { I would use a mobile payment system if I feel that the } \\
\text { Australian government will protect my rights against any } \\
\text { harm. }\end{array}$ & 0.936 & 0.984 \\
\hline
\end{tabular}


B) Weights and loading (After eliminating negative values)

\begin{tabular}{|c|c|c|c|c|}
\hline Constructs & Abbrev. & items & Weights & Loadings \\
\hline \multirow{5}{*}{ Personal factors } & PGE & Personal Characteristics - Gender & 0.204 & 0.108 \\
\hline & PAG & Personal Characteristics - Age & 0.714 & 0.692 \\
\hline & PED & Personal Characteristics - Education & 0.538 & 0.521 \\
\hline & PET & Personal Characteristics - Ethnicity & 0.424 & 0.480 \\
\hline & TR_1 & Trust is an essential factor in mobile payment adoption & 0.055 & 0.326 \\
\hline \multirow{4}{*}{ Trust } & TR_2 & $\begin{array}{l}\text { I would trust that my personal information is safe (meaning secure and } \\
\text { confidential) when making a mobile payment }\end{array}$ & 0.303 & 0.781 \\
\hline & TR_3 & $\begin{array}{l}\text { I would trust in a mobile payment service provided by an Australian } \\
\text { Bank (e.g. CBA, NAB, ANZ, Westpac, etc.) }\end{array}$ & 0.364 & 0.856 \\
\hline & TR_4 & $\begin{array}{l}\text { I would trust in a mobile payment service provided by my mobile } \\
\text { network operator (e.g. Telstra, Optus, Vodafone, etc.) }\end{array}$ & 0.363 & 0.880 \\
\hline & TR_5 & $\begin{array}{l}\text { I would trust in a mobile payment service provided by companies } \\
\text { other than a bank or mobile network operator (e.g. ApplePay, } \\
\text { SamsungPay, PayPal etc.) }\end{array}$ & 0.155 & 0.736 \\
\hline \multirow{4}{*}{ Behavioural factors } & BH_1 & I believe that using a mobile device to make a payment is easy & 0.441 & 0.882 \\
\hline & BH_2 & $\begin{array}{l}\text { I believe that mobile payment systems are useful if they provide a } \\
\text { faster service than other types of payment. }\end{array}$ & 0.501 & 0.919 \\
\hline & BH_4 & $\begin{array}{l}\text { I am going to use a mobile payment system if my close friends or } \\
\text { someone I trust are doing the same. }\end{array}$ & 0.215 & 0.701 \\
\hline & BH_5 & $\begin{array}{l}\text { Cost rather than security is important to me when it comes to adopting } \\
\text { a new payment system. }\end{array}$ & 0.003 & 0.202 \\
\hline \multirow{3}{*}{$\begin{array}{l}\text { Technological } \\
\text { factors }\end{array}$} & TECH_1 & I am familiar with using my smartphone for making payment & 0.603 & 0.881 \\
\hline & TECH_2 & How often do you change your smartphone? & 0.239 & 0.604 \\
\hline & TECH_3 & How often do you update software on your smartphone? & 0.426 & 0.761 \\
\hline $\begin{array}{l}\text { Organisational } \\
\text { factors }\end{array}$ & ORG_1 & $\begin{array}{l}\text { I have been choosing my mobile service provider based on the } \\
\text { reputation that they have in the market. }\end{array}$ & 0.834 & 0.931 \\
\hline \multirow{3}{*}{$\begin{array}{l}\text { Governmental } \\
\text { factors }\end{array}$} & ORG_2 & $\begin{array}{l}\text { I would consider using a mobile payment system if I feel that the } \\
\text { offered packaged benefits are greater than the risks }\end{array}$ & 0.378 & 0.591 \\
\hline & GOV_1 & $\begin{array}{l}\text { I feel that the Australian government has been changing the policies in } \\
\text { the mobile payment sector very often. }\end{array}$ & 0.192 & 0.427 \\
\hline & GOV_2 & $\begin{array}{l}\text { I would use a mobile payment system if I feel that the Australian } \\
\text { government will protect my rights against any harm. }\end{array}$ & 0.934 & 0.983 \\
\hline
\end{tabular}


C) Multicollinearity (Before and after eliminating negative values). Outer Variance Inflated Factor (VIF) values

\begin{tabular}{|c|c|c|c|}
\hline Constructs & & Before & After \\
\hline \multirow{5}{*}{ BEHAVIOURAL FACTORS } & BH_1 & 1.926 & 1.926 \\
\hline & BH_2 & 2.194 & 2.152 \\
\hline & BH_3 & 1.105 & - \\
\hline & BH_4 & 1.588 & 1.575 \\
\hline & BH_5 & 1.158 & 1.107 \\
\hline \multirow{2}{*}{ GOVERNMENTAL FACTORS } & GOV_1 & 1.068 & 1.068 \\
\hline & GOV_2 & 1.068 & 1.068 \\
\hline \multirow{2}{*}{ ORGANISATIONAL FACTORS } & ORG_1 & 1.070 & 1.070 \\
\hline & ORG_2 & 1.070 & 1.070 \\
\hline \multirow{5}{*}{ PERSONAL FACTORS } & PGE & 1.080 & 1.059 \\
\hline & PAG & 1.075 & 1.059 \\
\hline & PIN & 1.034 & - \\
\hline & PED & 1.009 & 1.008 \\
\hline & PET & 1.015 & 1.012 \\
\hline \multirow{4}{*}{ TECHNOLOGICAL FACTORS } & TECH_1 & 1.484 & 1.356 \\
\hline & TECH_2 & 1.212 & 1.212 \\
\hline & TECH_3 & 1.306 & 1.267 \\
\hline & TECH_4 & 1.240 & - \\
\hline \multirow{5}{*}{ TRUST FACTORS } & TR_1 & 1.144 & 1.144 \\
\hline & TR_2 & 1.649 & 1.649 \\
\hline & TR_3 & 2.015 & 2.015 \\
\hline & TR_4 & 2.312 & 2.312 \\
\hline & TR_5 & 1.775 & 1.775 \\
\hline
\end{tabular}

Inner Variance Inflated Factor (VIF) values

\begin{tabular}{lcc}
\hline & Trust Before & Trust After \\
\hline BEHAVIOURAL FACTORS & 2.107 & 2.032 \\
GOVERNMENTAL FACTORS & 1.422 & 1.435 \\
ORGANISATIONAL FACTORS & 1.292 & 1.278 \\
PERSONAL FACTORS & 1.312 & 1.316 \\
TECHNOLOGICAL FACTORS & 1.942 & 1.949 \\
\hline
\end{tabular}

